\title{
Determination of Aerosol Metals Pollutants in Falling Dust in Benghazi City, Libya
}

\author{
Sami H. Almabrok, Mussa M. Ali, Yasmin Y. Mohammed, Eman N. Zew, Badreya R. Hawiel \\ Department of Chemistry, Faculty of Science, University of Benghazi, Benghazi, Libya \\ Email:sami.almabrok@uob.edu.ly
}

How to cite this paper: Almabrok, S.H., Ali, M.M., Mohammed, Y.Y., Zew, E.N. and Hawiel, B.R. (2020) Determination of Aerosol Metals Pollutants in Falling Dust in Benghazi City, Libya. Open Access Library Journal, 7: e6642.

https://doi.org/10.4236/oalib.1106642

Received: July 23, 2020

Accepted: August 22, 2020

Published: August 25, 2020

Copyright $\odot 2020$ by author(s) and Open Access Library Inc.

This work is licensed under the Creative Commons Attribution International License (CC BY 4.0).

http://creativecommons.org/licenses/by/4.0/ (c) (i) Open Access

\begin{abstract}
The aim of this study is to determine the concentrations of selected aerosol metals in falling dust at different roadsides in Benghazi city. In order to do that, Flame atomic absorption spectroscopy (FAAS) technique has used to quantitative the areoles metals. Six composite samples were collected along roadsides in Benghazi city and each composite sample was represented average of five samples. The concentrations of aerosol metals of each site were based on density of traffic road, type of industrial activities and the number of population. Each measured sample was replicated three times to obtain representative and accurate values. Also, a statistical analysis including mean and standard deviation was carried out. Correlation coefficient of calibration curves of slandered selected metals was shown a good response, where the $\mathrm{R}^{2}$ value was ranged between 0.994 to 0.999 . The range of concentrations of the aerosol metals were varied as following: Cobalt $(90-344 \mathrm{mg} / \mathrm{kg})$, iron (120 $383 \mathrm{mg} / \mathrm{kg}$ ), lead (153 - $740 \mathrm{mg} / \mathrm{kg})$, zinc $(78-468.7 \mathrm{mg} / \mathrm{kg})$, copper $(80-180$ $\mathrm{mg} / \mathrm{kg}$ ), selenium (40 - $133 \mathrm{mg} / \mathrm{kg})$, cadmium $(90,344 \mathrm{mg} / \mathrm{kg})$, potassium $(318$ - $2932 \mathrm{mg} / \mathrm{kg})$, sodium (587.5 - $3006 \mathrm{mg} / \mathrm{kg})$, calcium $(286.6$ - $1185.7 \mathrm{mg} / \mathrm{kg}$ ) and magnesium (65 - $325.8 \mathrm{mg} / \mathrm{kg}$ ). A significant positive correlation was shown between each pair of measured elements $\mathrm{Pb} / \mathrm{Zn}, \mathrm{Pb} / \mathrm{Co}, \mathrm{Pb} / \mathrm{Cu}, \mathrm{Pb} / \mathrm{Se}$, $\mathrm{Zn} / \mathrm{Co}$ and $\mathrm{Zn} / \mathrm{Cu}$.
\end{abstract}

\section{Subject Areas}

Atmospheric Sciences

\section{Keywords}

Aerosol Metals, Sampling Sites, Street Dust, Dust, Flame Atomic Absorption Spectroscopy 


\section{Introduction}

The Earth's atmosphere is defined as the gaseous envelope surrounding the planet and it plays an important role in the transfer of energy between the Sun and the planet's surface; this process maintains the thermal equilibrium that supplies a suitable temperature range to the Earth. The Earth's atmospheric chemistry is directly related to oceans and surface processes; therefore, the oceans, the surface processes, and the atmosphere are especially important components for life (Salby, 1996) [1]. Particulate matter is defined as a suspension of fine solid or liquid particles in the gas phase. The main sources of particulate matter in the atmosphere are natural and anthropogenic emissions; natural sources include windborne dust, sea spray and volcanoes; anthropogenic activities include combustion of fuels (Seinfeld and Pandis, 2006) [2]. Tropospheric aerosol contains sulfate, ammonium nitrate, sodium, chloride, trace elements, carbonaceous material and water. Carbonaceous material includes elemental carbon and organic carbon. The elemental carbon is called black carbon, graphite carbon, or soot and is directly emitted into the troposphere from the combustion of fuels. The organic carbon is directly emitted or formed by condensation of low volatility organic gases. Anthropogenic emissions have increased dramatically over the past century, this increase has affected human health, reduced visibility in urban regional areas, and this led to acid deposition, and impacted the Earth's radiation balance. The visibility is reduced, when the light from the Sun is absorbed and scattered by the particles between the observer and the object, this decreases the contrast between the object and background sky and the consequence is to reduced visibility (Seinfeld and Pandis, 2006) [2]. Dust is classified as a type of aerosol in air pollution with diameters less than 500 micrometers. Dust aerosols can be formed from different sources such as soil dust by wind as an air pollution. However, dust encompasses minor amounts of many materials which may be found in the local atmosphere (Balram and Litrupa, 2012) [3]. Street dust does not remain deposited in place for a long time. This is due to the movement of vehicles and human activity can back into the atmosphere, where it contributes a significant amount of trace elements. There are two main sources of street dust: deposition of previously suspended particles (atmospheric aerosols) and displaced soil (Nasser and Inas, 2012) [4]. Heavy metals release in atmospheric particles maybe cause problem to ecosystem and side effect on the human being due to accumulation factor. This might be via inhalation or respiratory deposition. Toxic heavy metals such as arsenic, cadmium and lead in the atmosphere cause potential hazard. For this reason, WHO has given guidelines for these elements, which are presented in air and above the natural acceptable levels due to the anthropogenic activities. Aerosols and hydrometeors are identified and characterized by their size distribution and composition. The number density of aerosol particles decreases with increasing particle size; the number density of hydrometeor particles is less than that of aerosol particles, but the mass loading of hydrometeor particles is greater than those of aerosol particles. The aerosol particles can be 
divided into three categories: The nucleation mode contains particles with diameters less than $0.1 \mu \mathrm{m}$, these particles increase in size by coagulation and growth; only a few gases, such as sulfuric acid, water and some organic gases condense onto particles. The accumulation mode, when particles coagulate and grow to diameters between $0.1-2 \mu \mathrm{m}$, they are termed accumulation mode particles. Some of these particles are removed by rain, but they are still too light to be removed by sedimentation. The accumulation mode maybe sub-divided into submodes with diameters between $0.2 \mu \mathrm{m}$ and 0.5 to $0.7 \mu \mathrm{m}$. Accumulation mode particles are important for two reasons. First they affect health by penetrating into lungs. The second effect is visibility. The particles in nucleation and accumulation modes are called fine particles. The coarse mode consists of particles larger than $2 \mu \mathrm{m}$ in diameter, these particles originate from windblown dust, sea spray, volcanoes, and plants; these particles are heavy enough to sediment (Jacobson, 2002) [5]. Our respiratory system is efficient at removing aerosols, but if these aerosols fall within particular size ranges they are considered as highly concentrated, or toxic and may cause adverse health effects. They may also deposit on skin or eyes, generally, causing irritation, though more toxic effects may occur. Very small particles may pass through the skin and enter the body that way. Soluble particles may dissolve and pass through the skin. Suspended particulate with smaller sizes can absorb heavy metals and leads to tissue damage if penetrates lungs. The health effects of suspended toxic heavy metals on the human being might have become very dangerous when an active person typically inhales between 10,000 to 20,000 liters of air per day (Godwin et al., 2014) [6]. During inhalation, these fine suspended heavy metals can enter the lungs and also blood stream. However, several other organs can be affected than the lungs. It has been estimated that a man can live weeks without food and five days without water, but only five minutes without air (Godwin et al., 2014) [6]. Heavy metals become one of the major concerns over the world, which is grown over years. Contamination by dust containing heavy metals could be ended by settling in soil and find their way to reach plants, animals and humans beings. Heavy metals by accumulation factor threats human health, plant growing and animals life (Shinggu et al., 2010) [7].

\section{Experimental Work}

\subsection{Chemical and Reagents}

All the reagents and materials were used at high purity ( $\geq 95 \%)$; these materials have been ordered from Sigma-Aldrich. Pure nitric acid (99\%), hydrochloric acid (99\%) and hydrogen peroxide (used as digestion) were supplied by BOC.

\subsection{Flame Atomic Absorption Spectroscopy (FAAS)}

An novAA ${ }^{\mathrm{R}}$ 400P Model flame atomic absorption spectrophotometer (FAAS) equipped with hollow cathode lamps was used for the determination of selected aerosols metals. Each element has optimum contentions: Wavelength, nm, HCL 
current, $\mathrm{mA}$, acetylene flow rate, $1 / \mathrm{min}$, air flow rate, $1 / \mathrm{min}$ and slit, $\mathrm{nm}$. This is to increase the sensitivity and selectivity oo determination the studied aerosols metals.

\subsection{Sampling}

Random a strategy method was used to collect all the samples and six composite samples (each one representative five samples, which was covered all targeted area) from different areas in Benghazi city. At least three replicate samples were collected from each sampling site. Roadsides falling dust samples were taken under very accurate and precise procedure to avoid any contamination or loss of the studied samples. Samples were collected from Jamal Abdul Nasser street, Al kuwafyah roadside, Venesah street, Garyuonis roadside, Tripoli roadside and Al Gawarishah (see Figure 1).

\subsubsection{Sampling Collection}

Samples were collected using vacuum pump. Figure 2 shown the filter paper was connected with pressure regulator and vacuum pump. The volume of collected falling dust samples containing aerosols metals was measured from flow meter readings (flow rate was 25 to $70 \mathrm{CFM}$ (Cubic feet of falling dust per minute)). This was running for 12 hours from 7 am to $7 \mathrm{pm}$ in different places using filter papers fixed properly in stainless plate. Collected dust containing aerosols metals were stored at room temperature after being placed in a plastic bag to avoid any contamination from surrounded atmosphere.

\subsubsection{Sample Preparation}

Falling dust samples were collected using cellulose filter membrane pore size 0.22 $\mu \mathrm{m}$, diameter $0.47 \mathrm{~mm}$. The net weight of collected dust samples (range between 0.1 $\mathrm{g}-0.2 \mathrm{~g}$ ). All the samples were dried at $100^{\circ} \mathrm{C}-110^{\circ} \mathrm{C}$; this to drive out moisture.

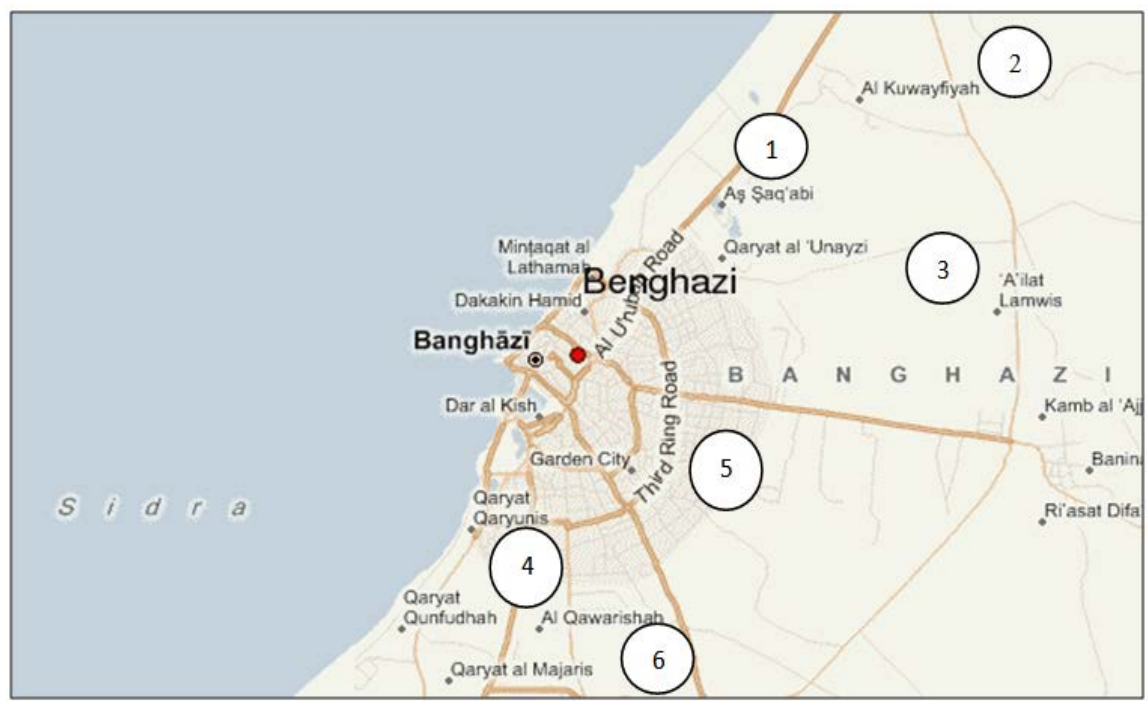

Figure 1. Map illustrating the sampling sites in Benghazi city. (Source: https://satellites.pro/Benghazi map). 


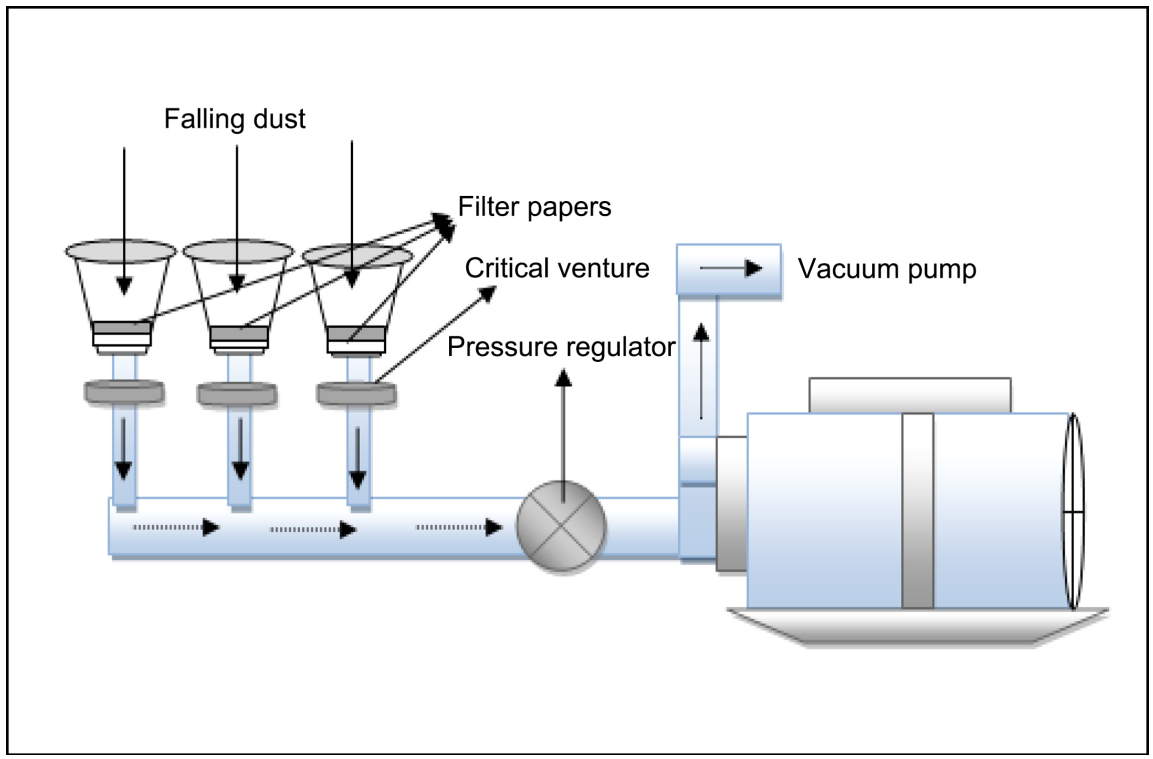

Figure 2. Schematic of collected falling dust using vacuum pump system.

Samples were kept in a petri dish to prevent any contamination. Filter paper including falling dust was placed in $50 \mathrm{ml}$ beaker and then $10 \mathrm{ml}$ of concentrated highly pure of nitric acid was added to the samples. The samples were heated slowly to digest; this was carried out until the amount of $10 \mathrm{ml}$ of concentrated nitric acid containing sample was reduced between 2 to $3 \mathrm{ml}$ due to the evaporation and then $5 \mathrm{ml}$ of concentrated nitric acid was added to the sample and heated again. This step was repeated more than one time to insure the digestion of sample was completely achieved. The final extracts were filtered into a $100 \mathrm{ml}$ polyethylene volumetric flask through $0.45 \mathrm{~mm}$ filters and then diluted to $100 \mathrm{ml}$ using distilled water.

\subsubsection{Standard Calibration Curves of the Studied Aerosols Metals}

All calibration curves for the studied metals (see Figures 3-12) have shown a good response and reproducibility. Correlation coefficients for standard selected metals was ranged between 0.959 to $0.999 \mathrm{R}^{2}$.

\section{Results and Discussion}

There are different factors that affect the falling dust, such as grain size, physical properties of module surfaces, type of glass, texture or antireflection, humidity and wind. In this work, the target was quantitative of some selected aerosols metals that can found in the falling dust due to the pollution. Particulate matter (PM) samples of falling dust containing metals in Benghazi city were analyzed to determine the concentrations of $\mathrm{Co}, \mathrm{Fe}, \mathrm{Pd}, \mathrm{Zn}, \mathrm{Cu}, \mathrm{Se}, \mathrm{K}, \mathrm{Na}, \mathrm{Ca}$, and $\mathrm{Mg}$. The result obtained for selected aerosols metals can be illustrated in Figures 13-22. As shown in figures from 13 to 22 , the concentrations of falling dust containing aerosols metals were varied depending on the site. Concentrations of cobalt were ranged between 90 to $344 \mathrm{mg} / \mathrm{kg}$, concentrations of iron were ranged between 
120.5 to $383.4 \mathrm{mg} / \mathrm{kg}$, concentrations of lead were ranged between 153 to 740 $\mathrm{mg} / \mathrm{kg}$, concentrations of zinc were ranged between 78.1 to $468.7 \mathrm{mg} / \mathrm{kg}$, concentrations of copper was ranged between 80.3 to $219 \mathrm{mg} / \mathrm{kg}$, concentrations of selenium were ranged between 40 to $133 \mathrm{mg} / \mathrm{kg}$, concentrations of potassium were ranged between 873.3 to $3181 \mathrm{mg} / \mathrm{kg}$, concentrations of sodium were ranged between 587.6 to $3006 \mathrm{mg} / \mathrm{kg}$, concentrations of calcium were ranged between 286.6 to $1185.7 \mathrm{mg} / \mathrm{kg}$, concentrations of magnesium were ranged between 64.9 to $325.8 \mathrm{mg} / \mathrm{kg}$. Garyuonis roadside and Tripoli roadside have shown the largest values for all the falling dust of measured elements. The reason for that, it might be referred to the industrial activities in these areas. Also, the traffic density in these areas an important factor to increase the concentrations of the measured elements in falling dust. Figures 23-28 are shown a significant positive correlation between each pairs of measured element $\mathrm{Pb} / \mathrm{Zn}, \mathrm{Pb} / \mathrm{Co}, \mathrm{Pb} / \mathrm{Cu}, \mathrm{Pb} / \mathrm{Se}$, $\mathrm{Zn} / \mathrm{Co}$ and $\mathrm{Zn} / \mathrm{Cu}$.

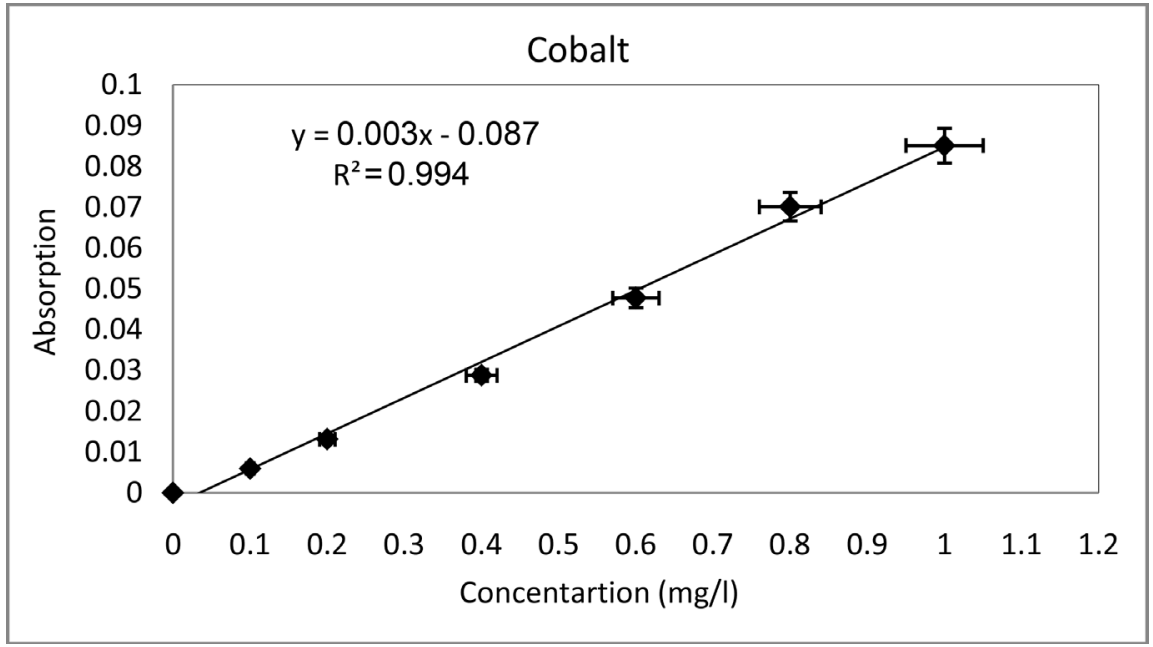

Figure 3. Calibration curve for Cobalt.

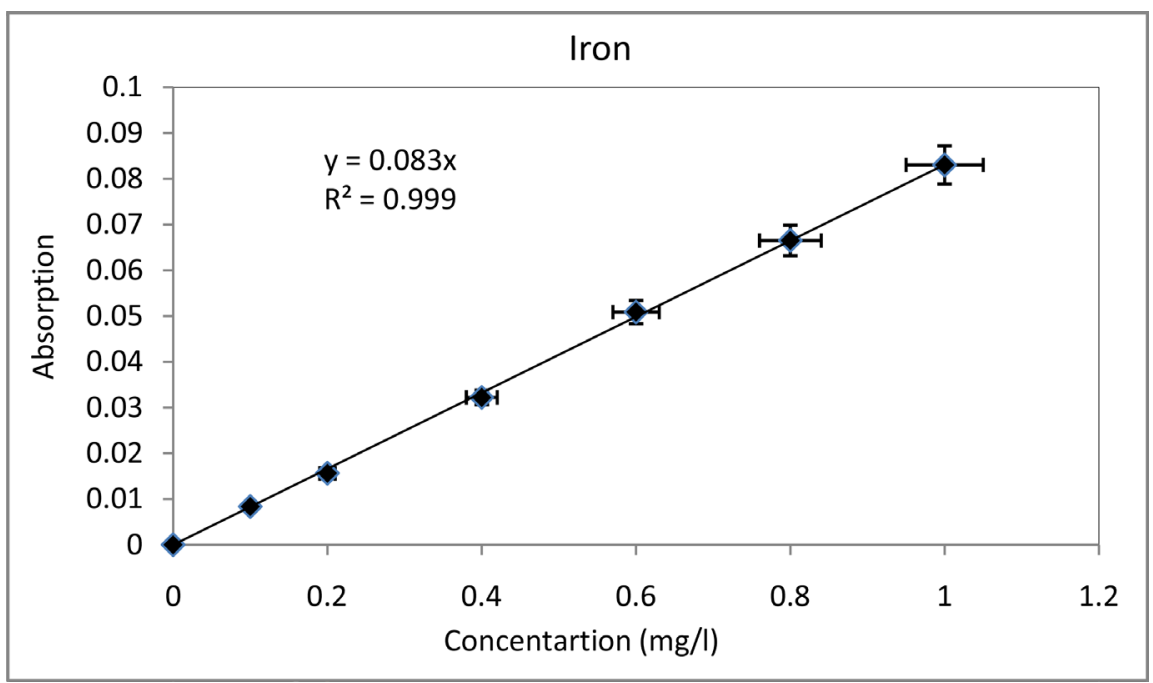

Figure 4. Calibration curve for Iron. 


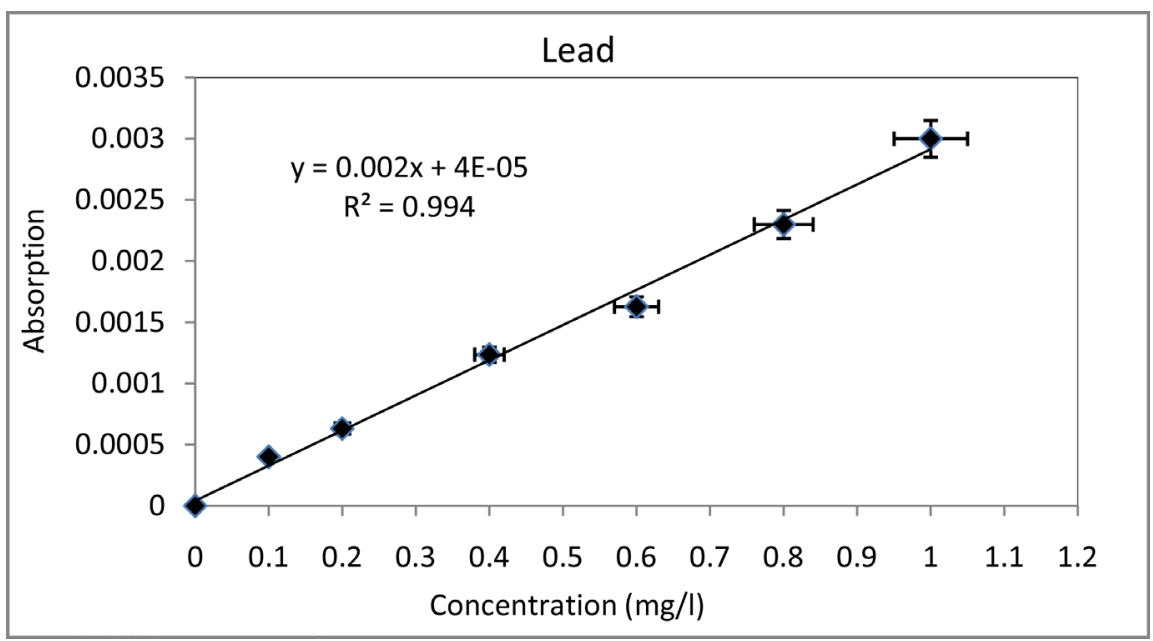

Figure 5. Calibration curve for Lead.

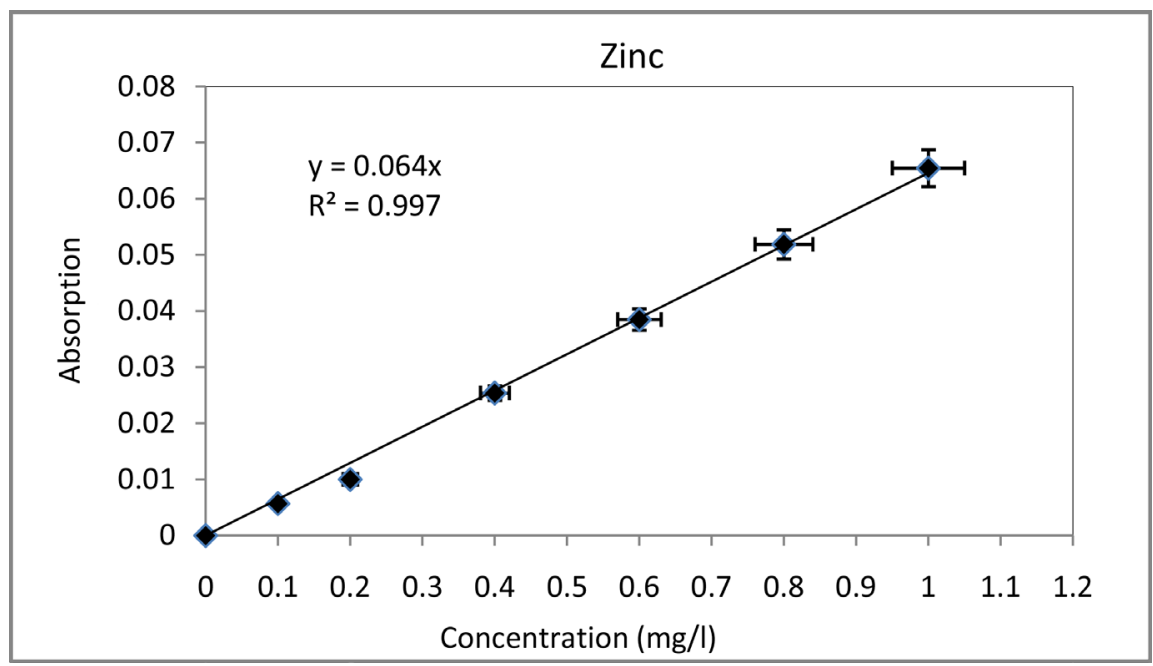

Figure 6. Calibration curve for Zinc.

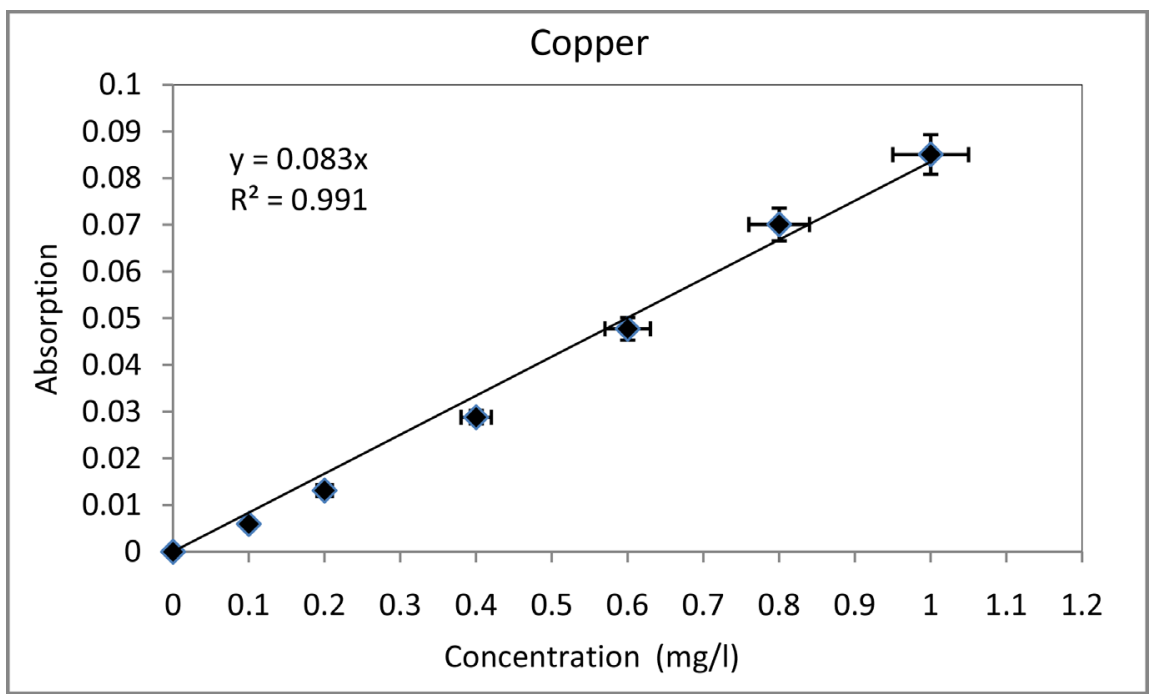

Figure 7. Calibration curve for Copper. 


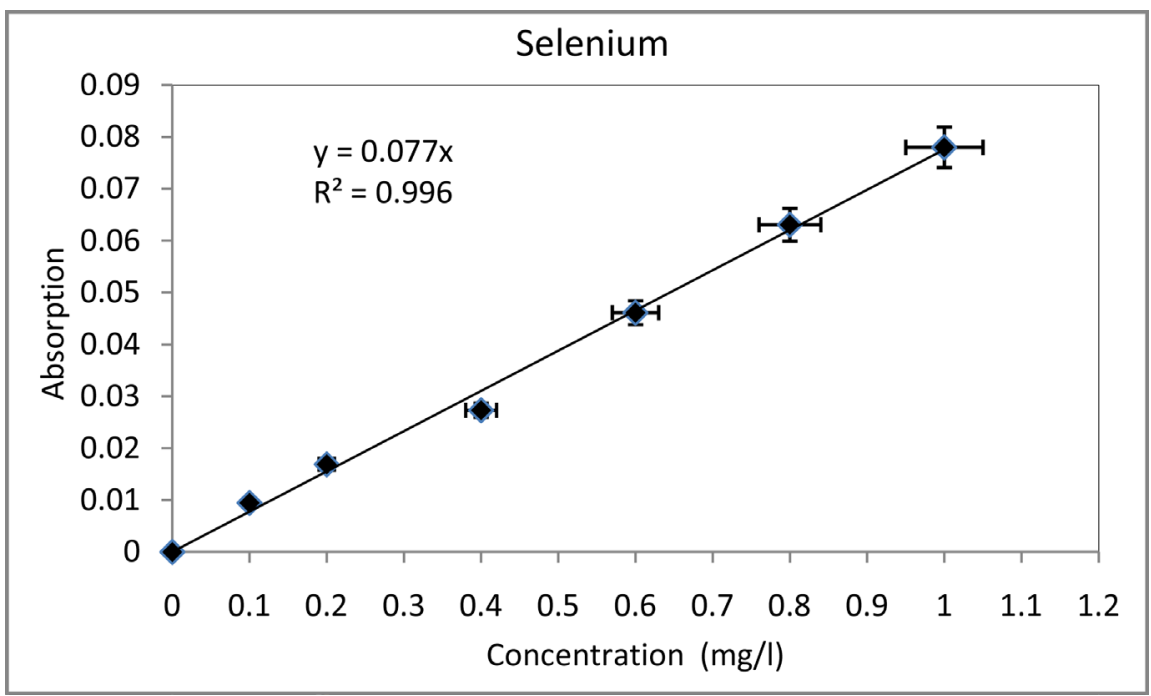

Figure 8. Calibration curve for Selenium.

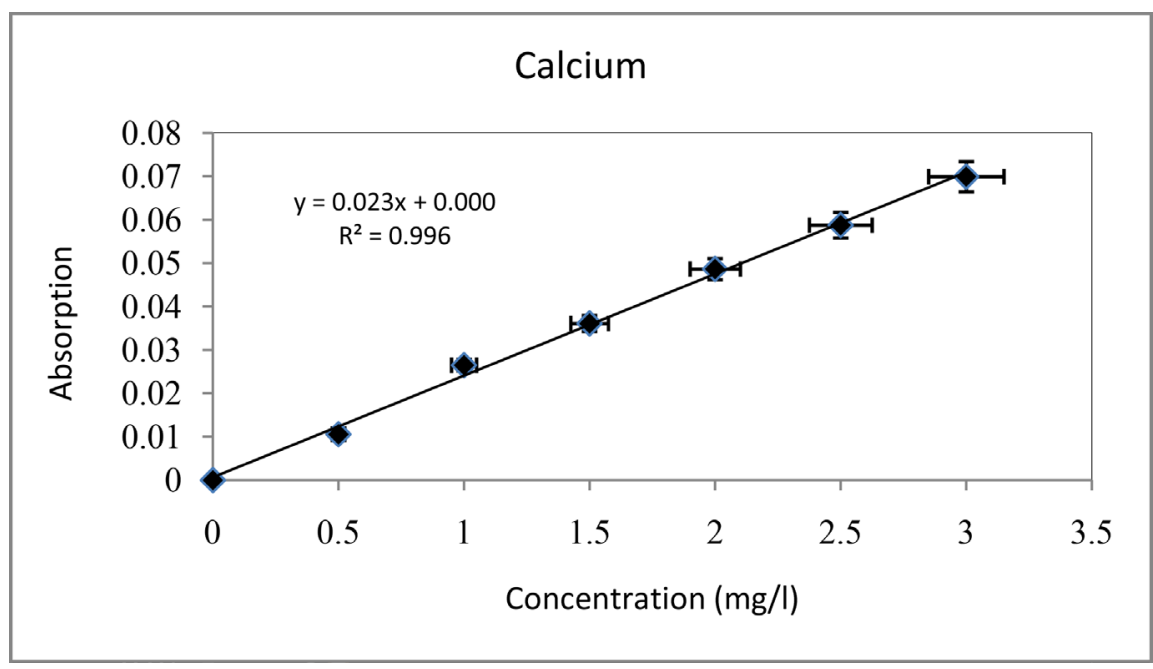

Figure 9. Calibration curve for Calcium.

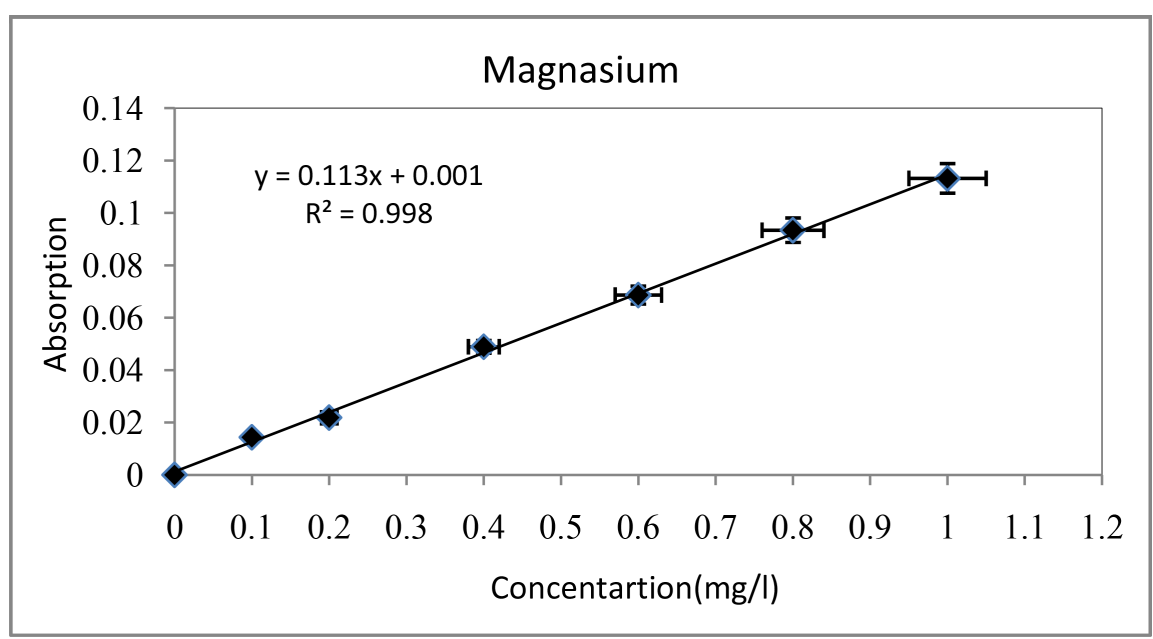

Figure 10. Calibration curve for Magnesium. 


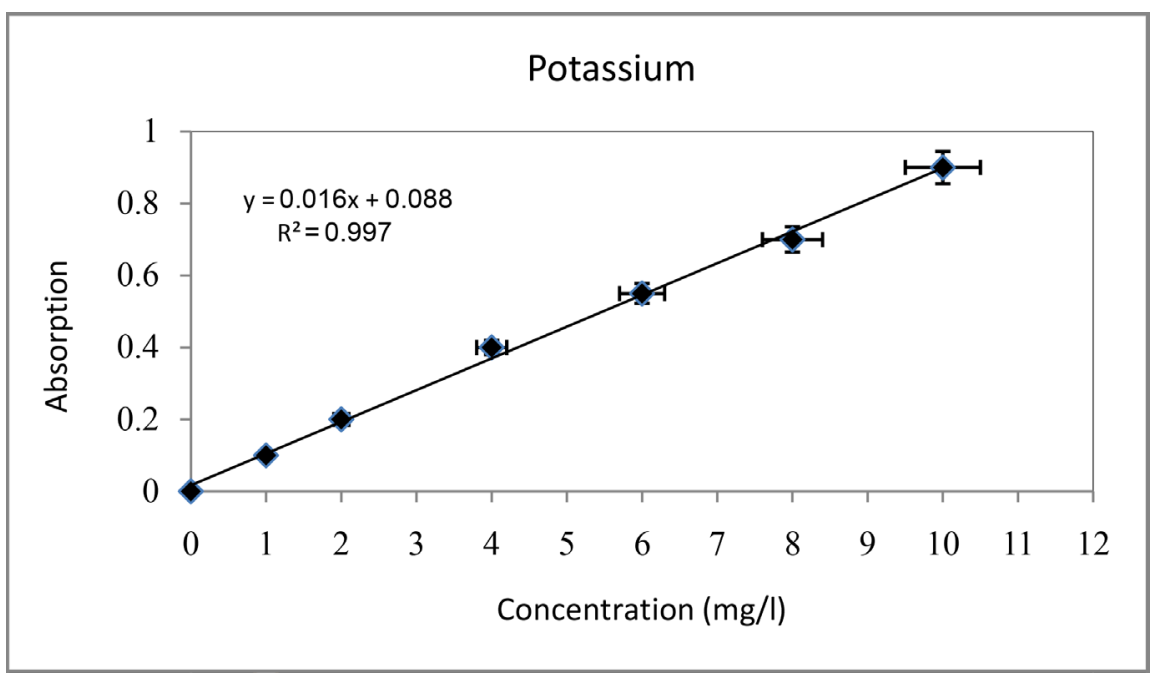

Figure 11. Calibration curve for Potassium.

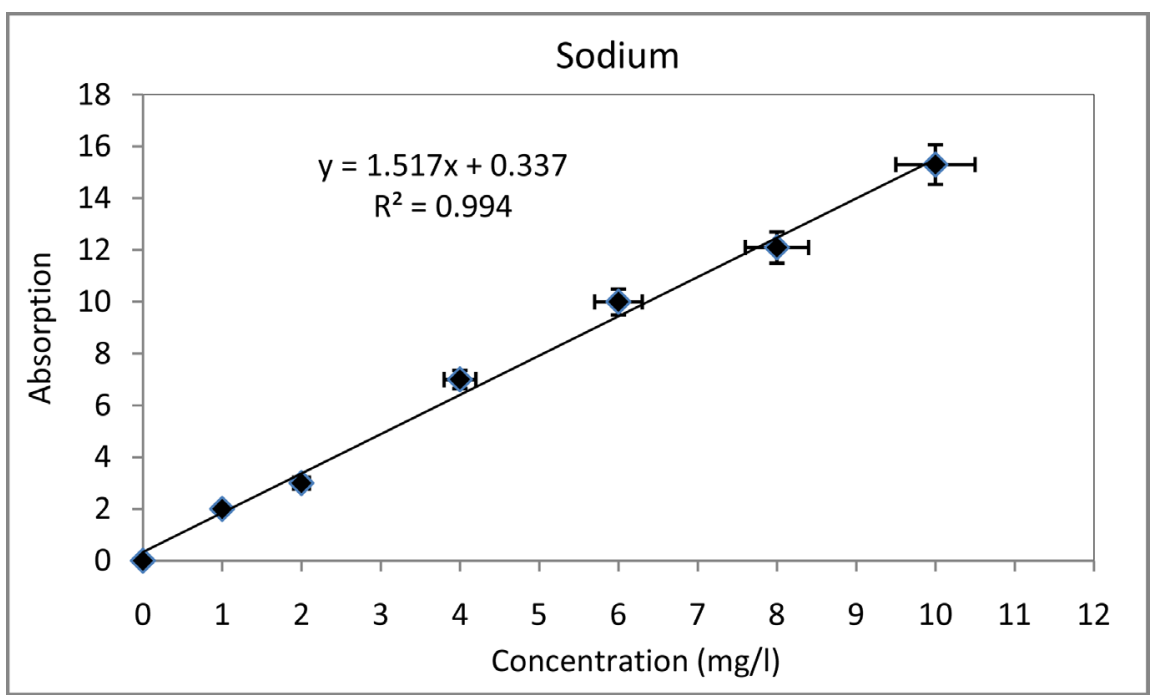

Figure 12. Calibration curve for Sodium.

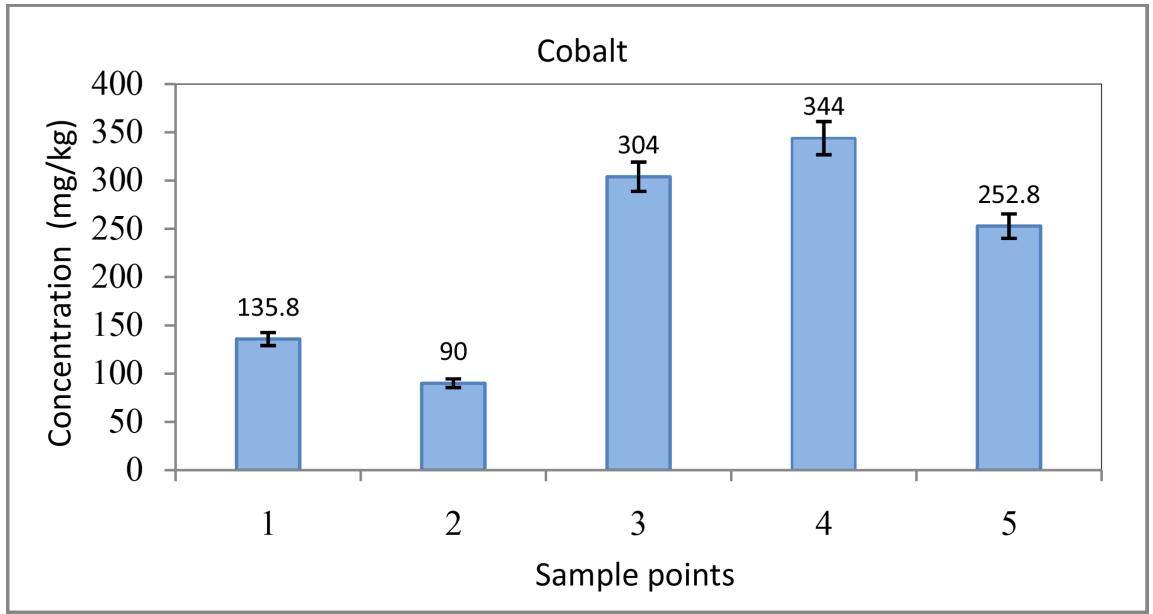

Figure 13. Cobalt concentrations in falling dust sample. 


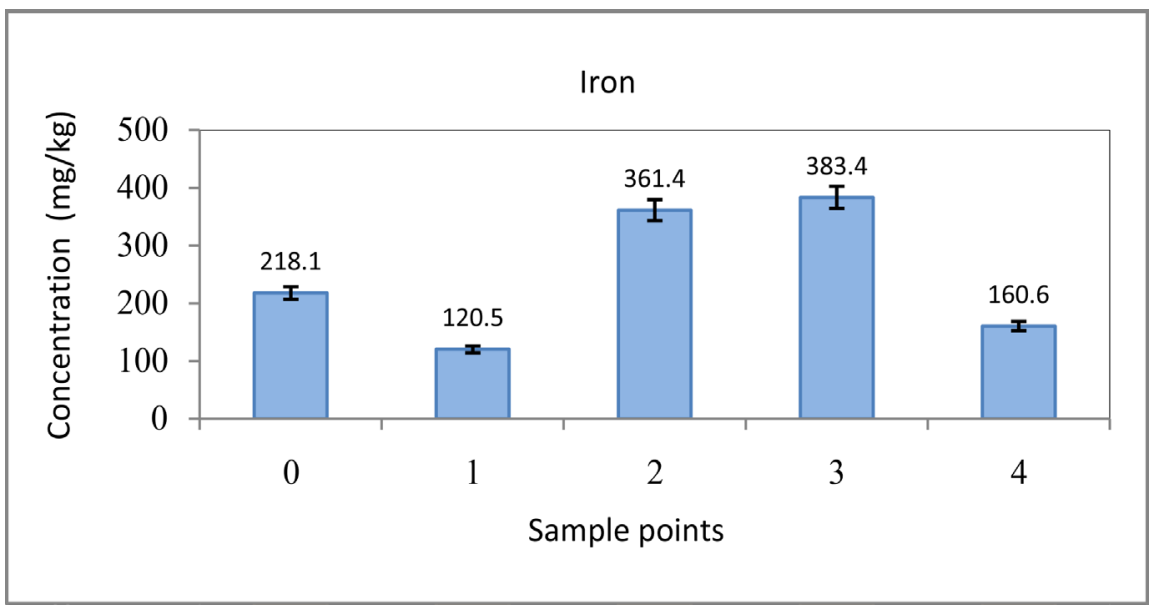

Figure 14. Iron concentrations in falling dust sample.

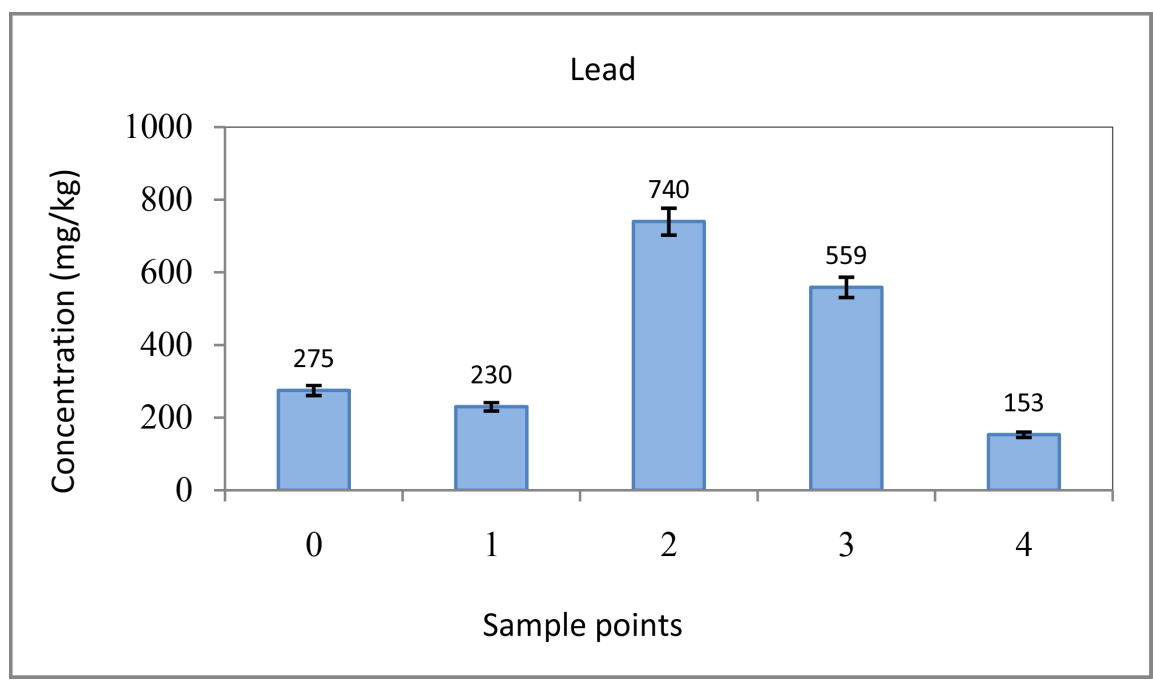

Figure 15. Lead concentrations in falling dust sample.

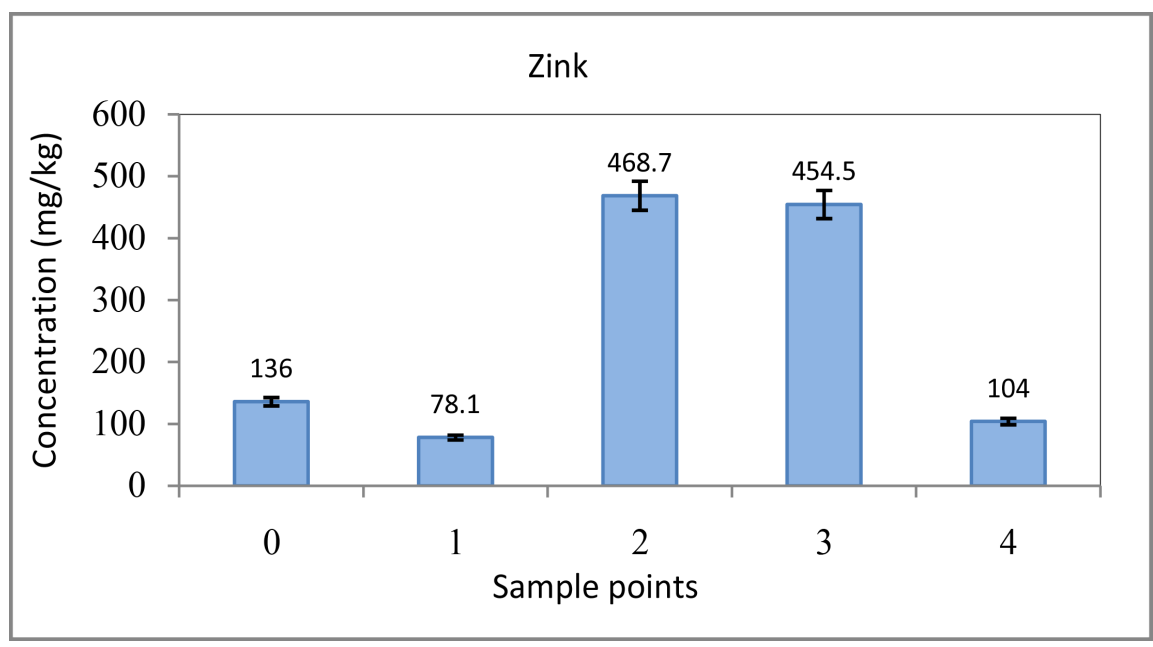

Figure 16. Zink concentrations in falling dust sample. 


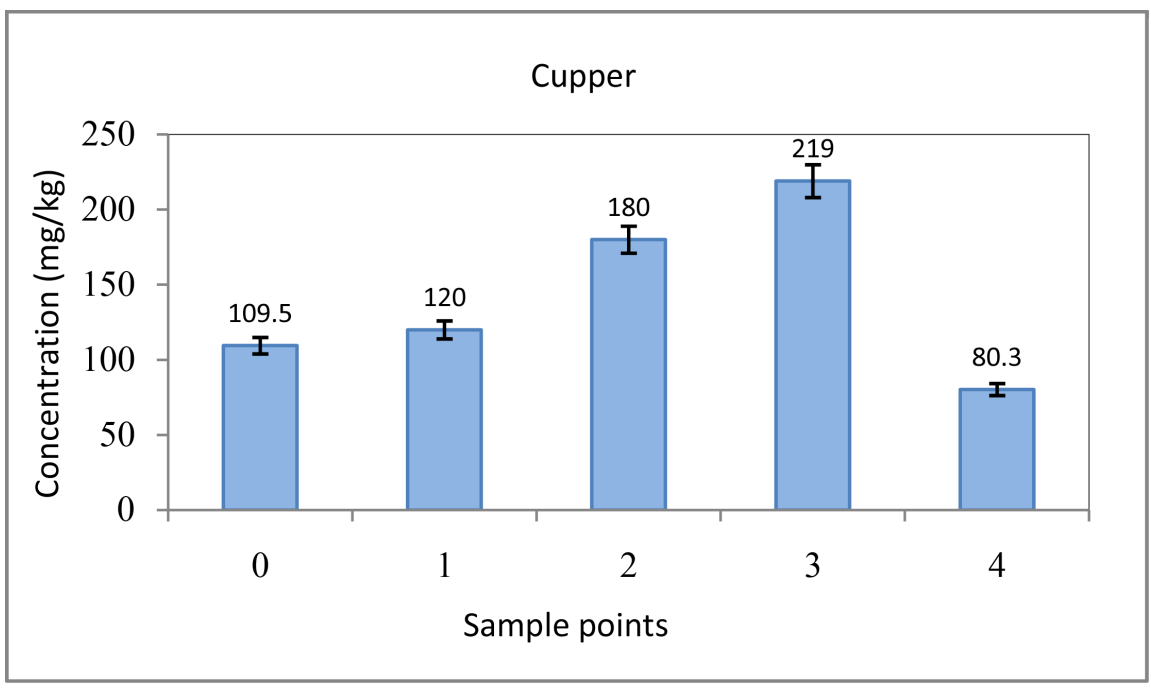

Figure 17. Cupper concentrations in falling dust samples.

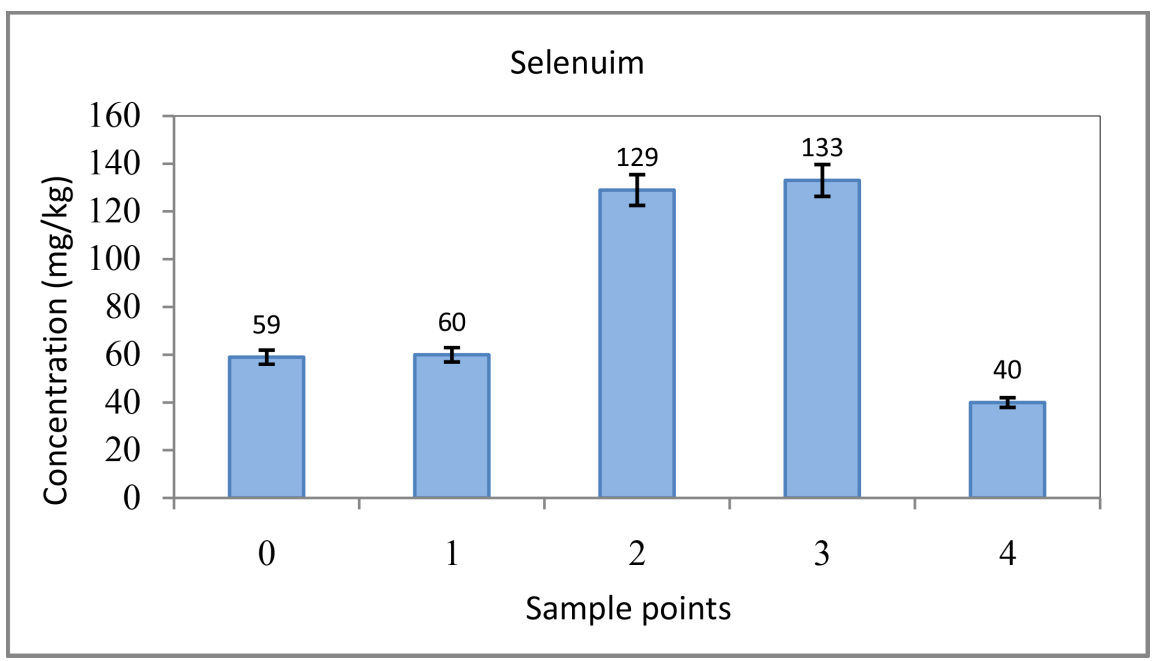

Figure 18. Selenium concentrations in falling dust samples.

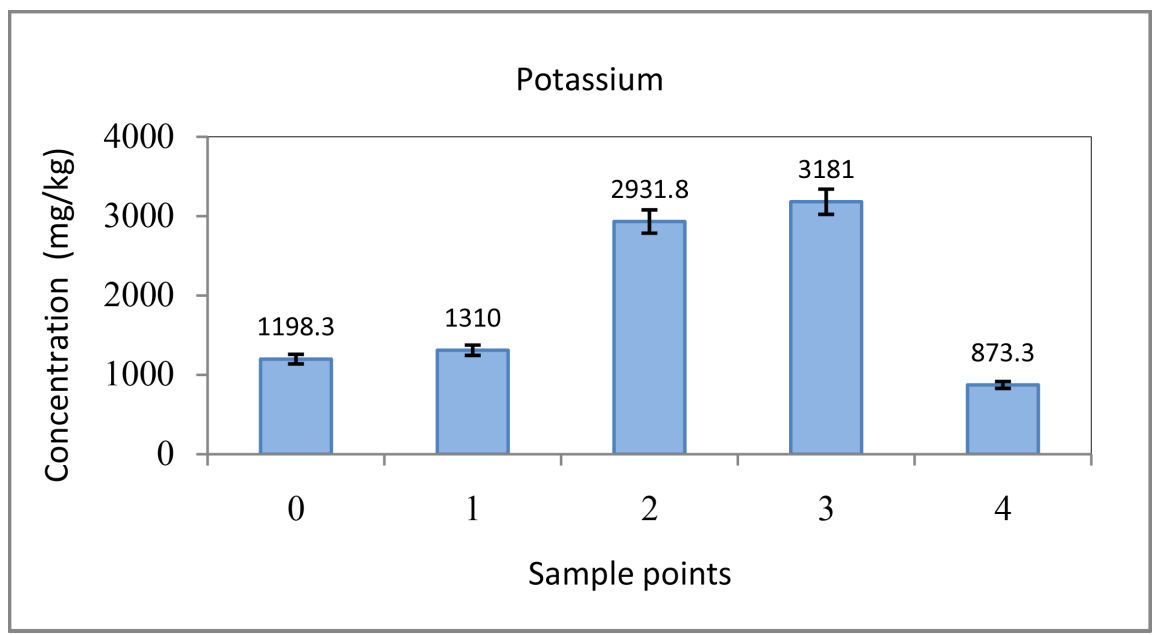

Figure 19. Potassium concentrations in falling dust samples. 


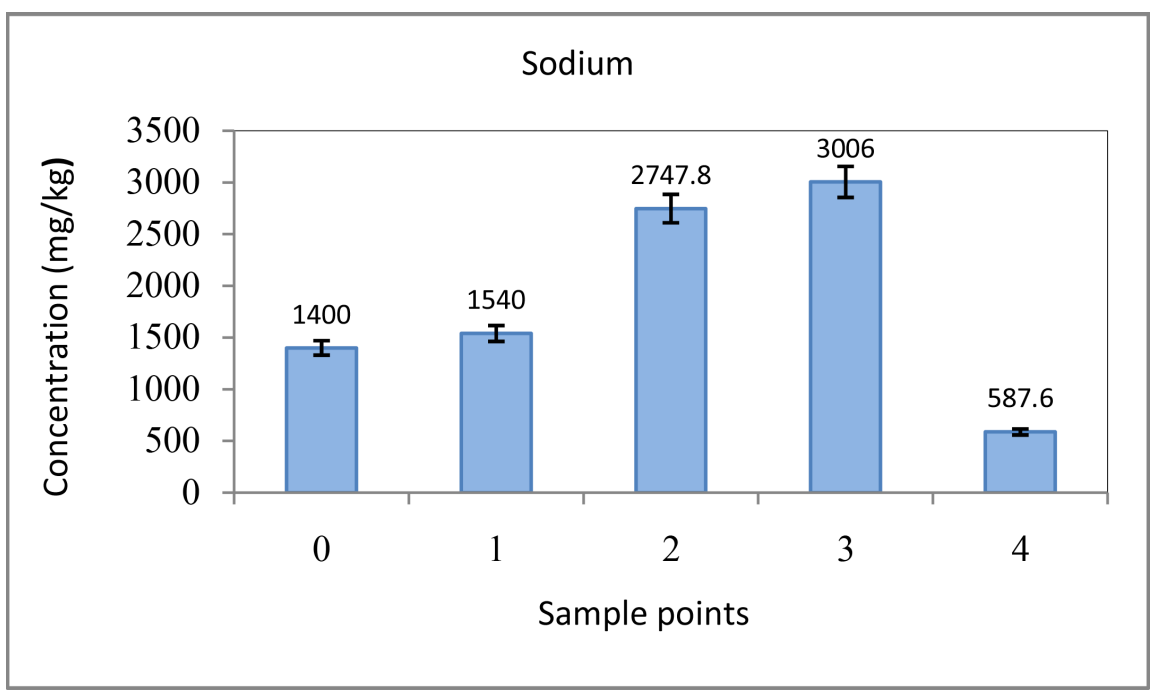

Figure 20. Sodium concentrations in falling dust samples.

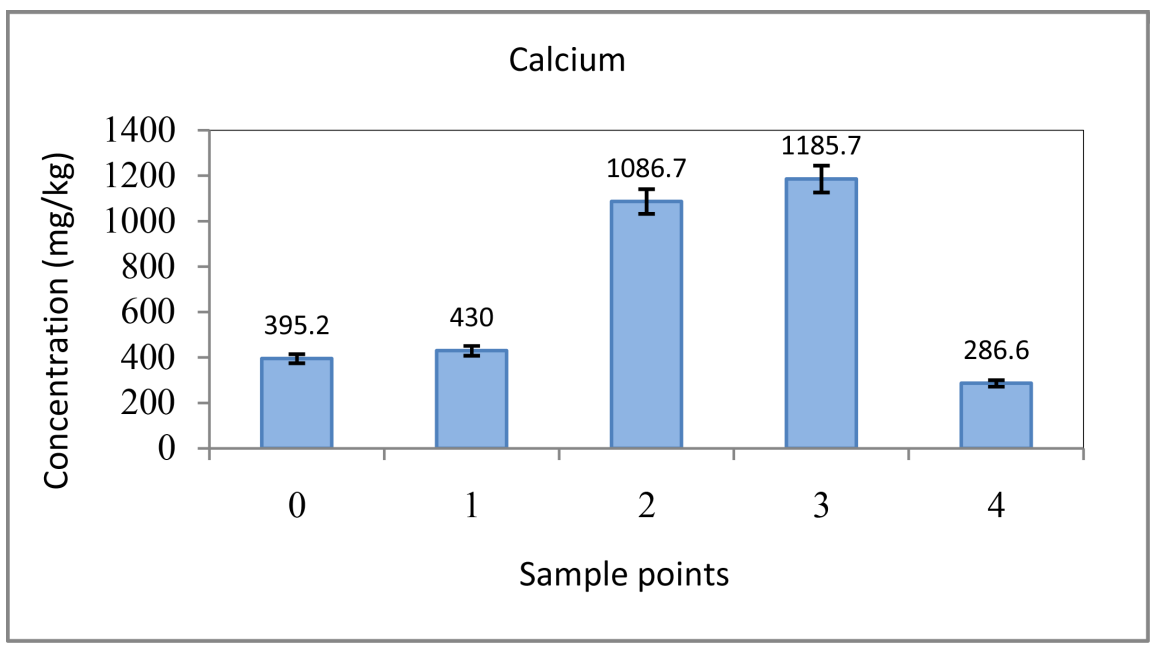

Figure 21. Calcium concentrations in falling dust samples.

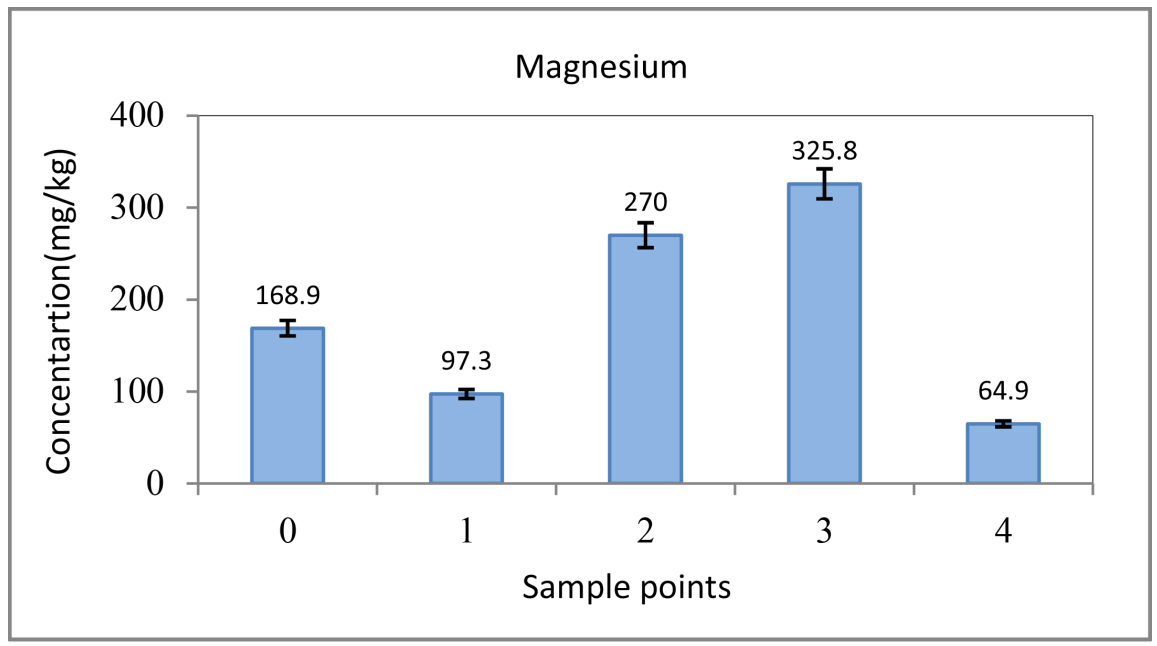

Figure 22. Magnesium concentrations in falling dust samples. 


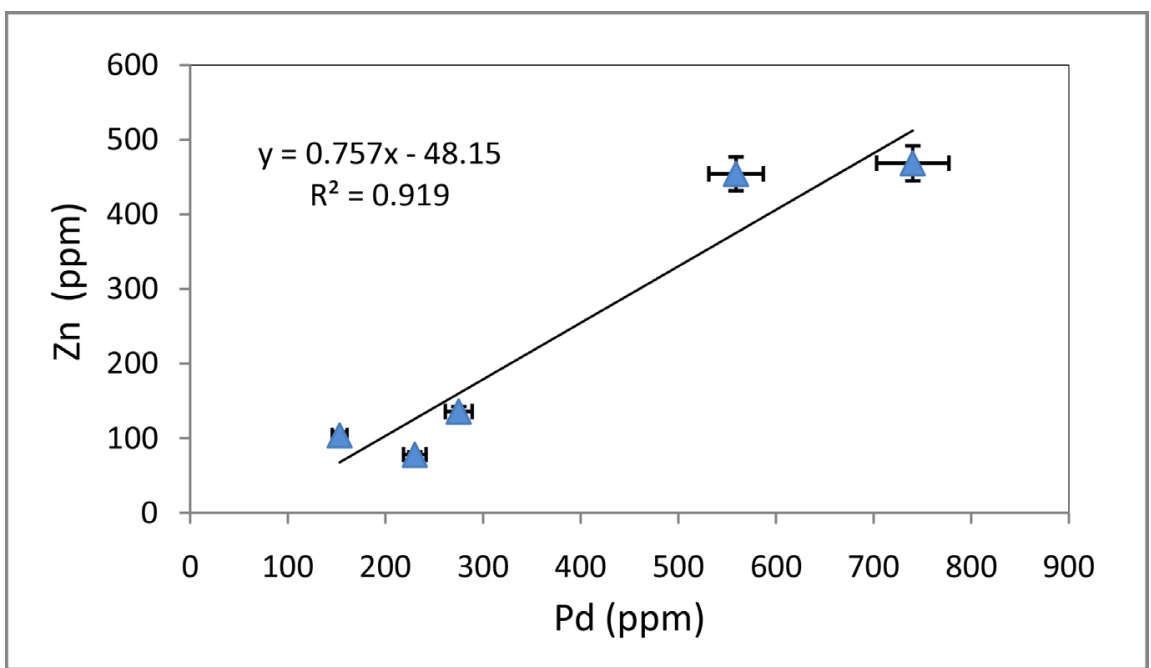

Figure 23. Shown the correlation between $\mathrm{Pb}$ and $\mathrm{Zn}$ concentrations.

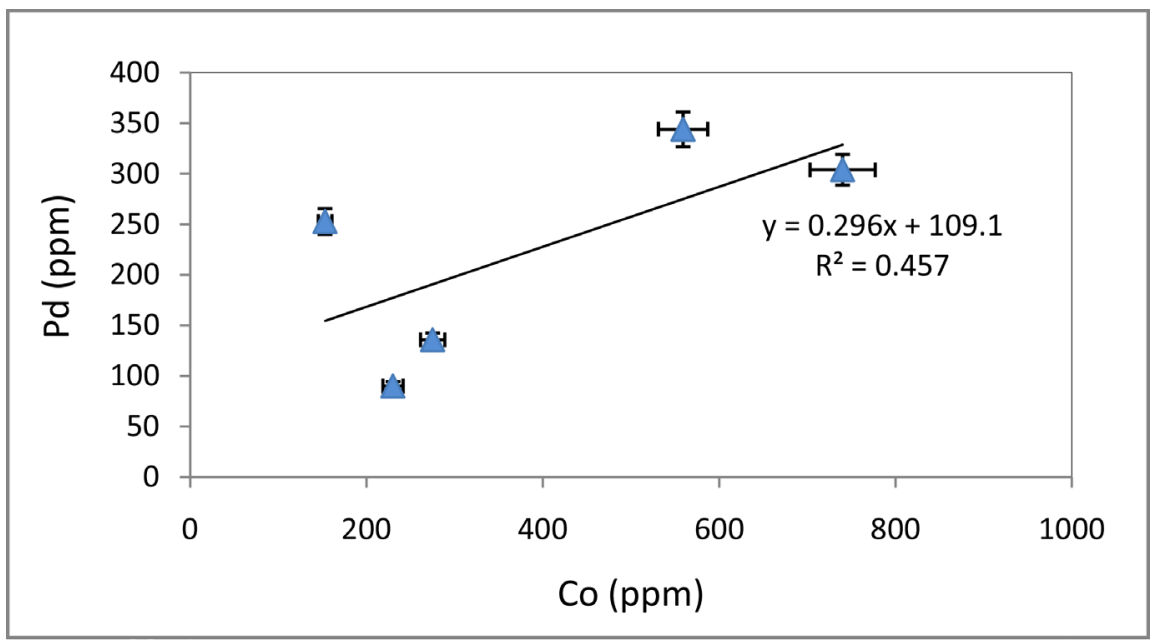

Figure 24. Shown the correlation between $\mathrm{Pb}$ and Co concentrations.

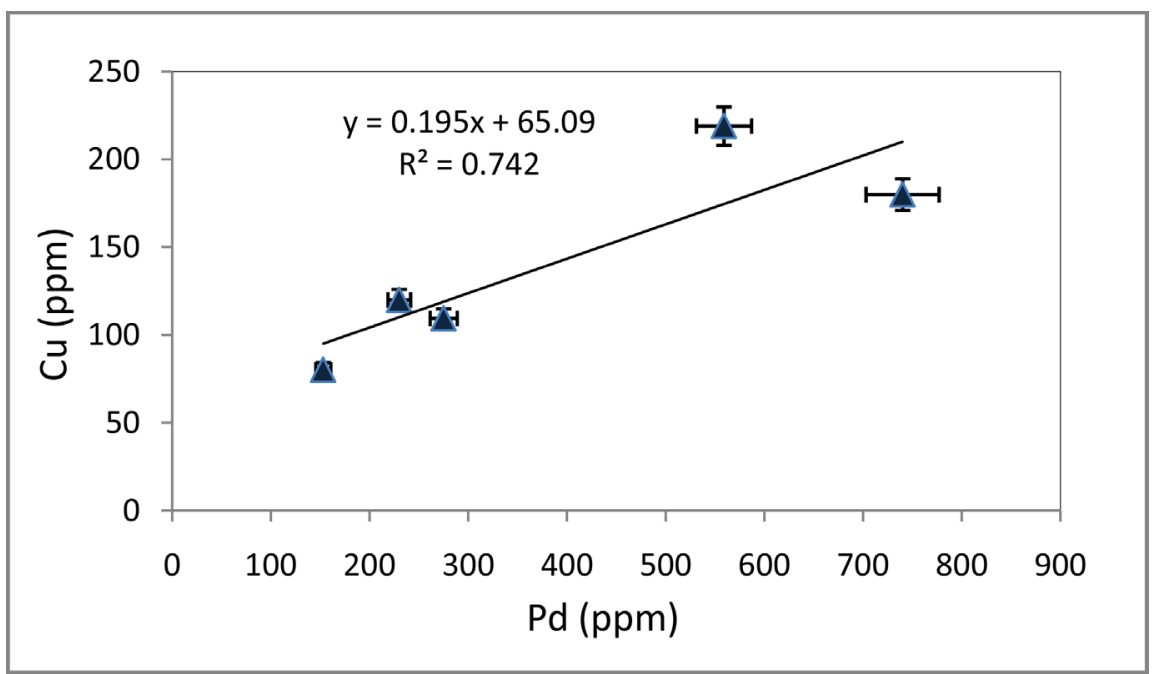

Figure 25. Shown the correlation between $\mathrm{Pb}$ and $\mathrm{Cu}$ concentrations 


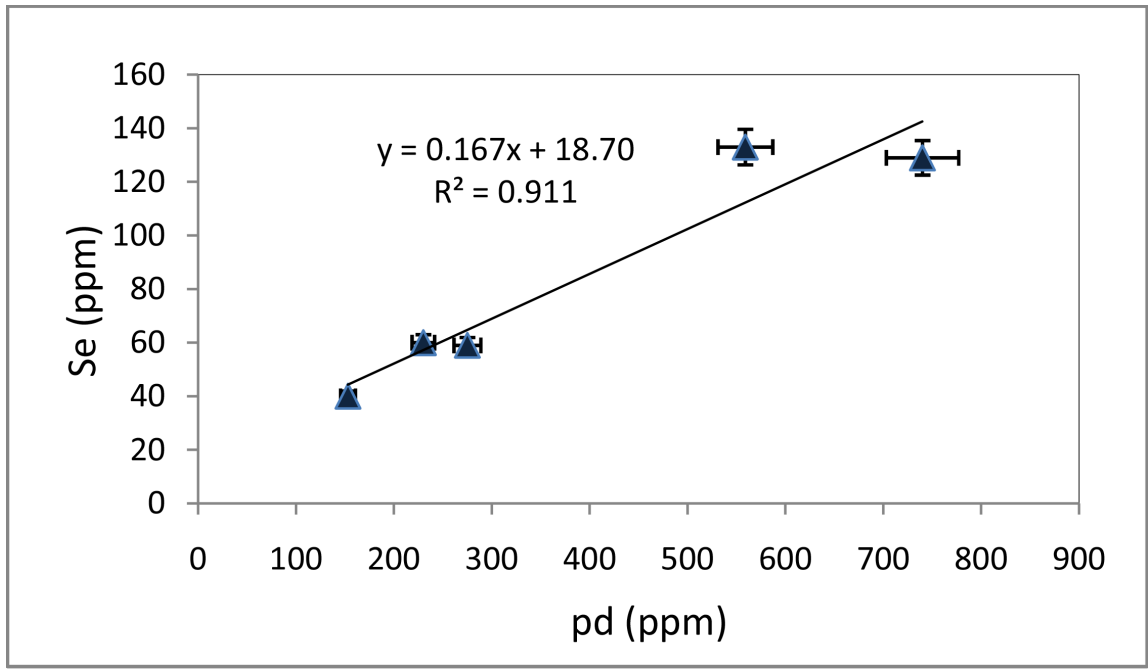

Figure 26. Shown the correlation between $\mathrm{Pb}$ and Se concentrations.

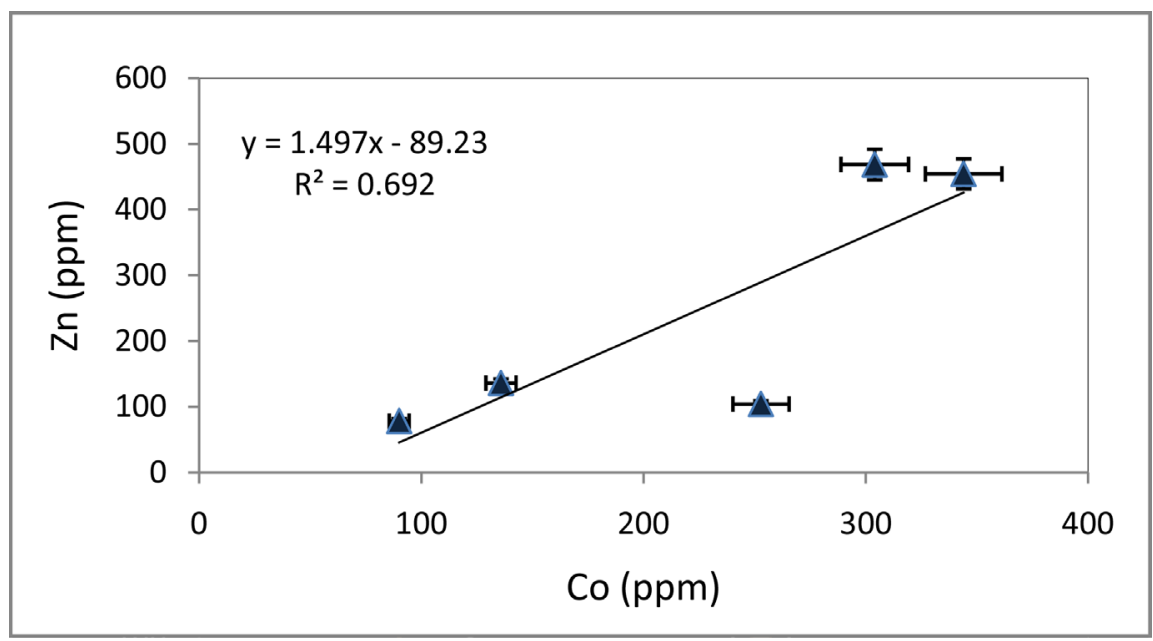

Figure 27. Shown the correlation between Co and $\mathrm{Zn}$ concentrations.

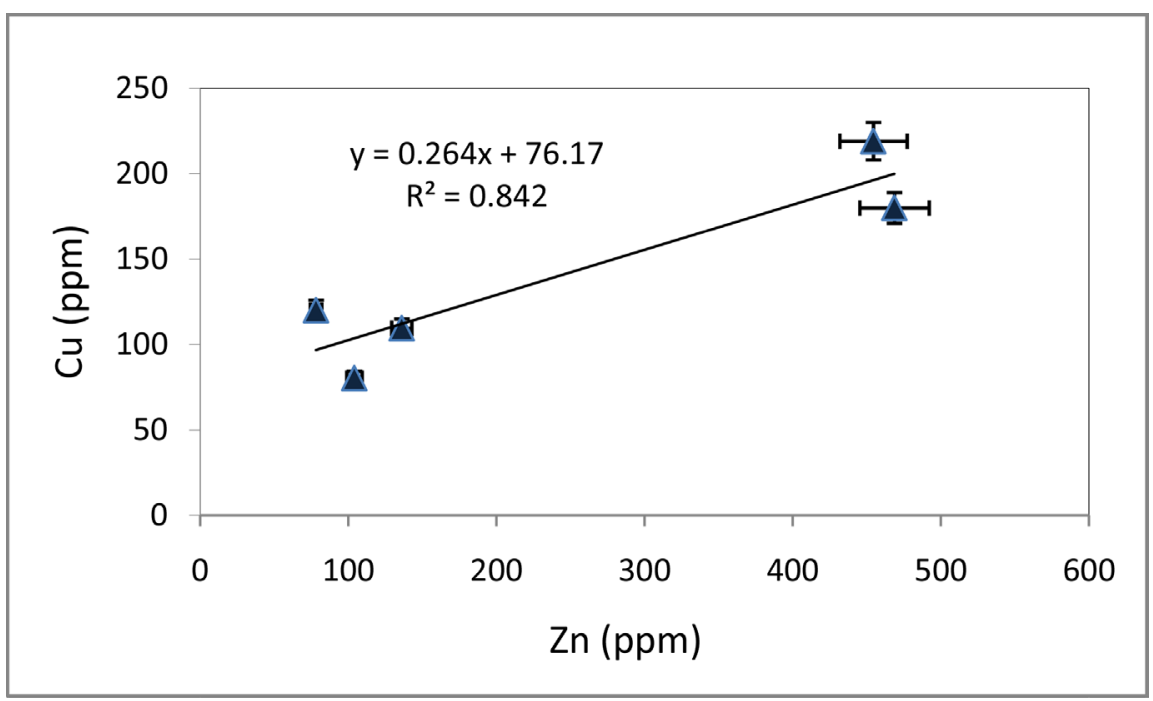

Figure 28. Shown the correlation between $\mathrm{Zn}$ and $\mathrm{Cu}$ concentrations. 


\section{Conclusion}

Aerosols metals pollutants and their impact on environmental and human health are some of the important concerns over the world in recent years. In this study, the concentrations of aerosol falling dust were varied based on the location, but most of the aerosol metals were given higher concentrations than expected comparing with previous studies. In general, the concentrations of aerosols metals in this work were increased with increased the movement of traffic in those particular areas, density of population and industrial activities. This can be noticed in Garyuonis roadside and Tripoli roadside, which the highest concentrations for most measured elements. Aerosols metals concentrations may vary from place to place depending on pollutant types and accumulation and/or depositional factor. Specific metal abundance may indicate source and degree of contamination with respect to environmental stress. A significant positive correlation was observed between most pairs of studied aerosols metals. The concentrations of aerosols metals are given good profile for distribution of falling dust aerosols metals among Benghazi city, also revealed a better understanding of concentrations the levels of aerosols heavy metals contamination in studied areas.

\section{Conflicts of Interest}

The authors declare no conflicts of interest regarding the publication of this paper.

\section{References}

[1] Salby, M.L. (1996) Fundamental of Atmospheric Physics. Academic Press, Cambridge.

[2] Seinfeld, J.H. and Pandis, S.N. (2006) Atmospheric Chemistry and Physical. $2^{\text {nd }}$ Edition, John Wiley \& Sons, New York.

[3] Balram. A. and Litrupa, S. (2012) Evaluation of Heavy Metal Contamination in Road Dust Fallout of Bhilai City. International Journal of Advanced Engineering Research and Studies, 1, 81-83.

[4] Nasser, M.A. and Inas, A.S. (2012) Heavy Metals Contamination in Roadside Dust along Major Roads and Correlation with Urbanization Activities in Cairo, Egypt. Journal of American Science, 8, 379-389.

[5] Jacobson, M.Z. (2002) Atmospheric Pollution, History, Science, and Regulation. Cambridge University Press, Cambridge.

[6] Mafuyai, G.M. Eneji, I.S. and Sha'Ato, R. (2014) Concentration of Heavy Metals in Respirable Dust in Jos Metropolitan Area, Nigeria. Open Journal of Air Pollution, 3 , 10-19. https://doi.org/10.4236/ojap.2014.31002

[7] Shinggu, D.Y., Ogugbuaja, V.O., Toma, I. and Barminas, J.T. ( 2010) Determination of Heavy Metal Pollutants in Street Dust of Yola, Adamawa State, Nigeria. African Journal of Pure and Applied Chemistry, 4, 17-21. 